\title{
Interdisciplinary approach in a patient diagnosed with prostate cancer
} and spine metastases

\section{Abstract}

Prostate cancer is one of the malignant tumours in which treatment of bone metastases is a significant clinical problem. In this article 66-year-old patient diagnosed with prostate cancer and multiple metastases to all parts of the spine with accompanying neuropathic pain of severe intensity, which disabled self-moving of a patient is presented. The patient was not qualified for surgery during neurosurgeon consultation. During palliative care provision for the patient by an interdisciplinary team of Home Hospice composed pharmacology treatment of pain was introduced using oxycodone/naloxone, ketoprofen and adjuvant analgesics: zoledronate acid with calcium and vitamin D supplementation, pregabalin and dexamethasone. Stability of the spine was provided through high trunk orthosis in order to minimize the risk of spine damage associated with rehabilitation. A significant decrease in pain, constipation and anxiety intensity was achieved with an improvement of overall performance status and quality of life, which enabled a further anticancer treatment and palliative radiotherapy. The submitted case indicates on a necessity of palliative care provided by the interdisciplinary team for patients diagnosed with prostate cancer and dissemination to bones and severe pain intensity, which significantly increases a chance for obtaining satisfactory analgesia, improvement in the quality of life and a possibility of continuing anticancer and symptomatic treatment.

Palliat Med Pract 2018; 12, 4: 207-213

Key words: bone pain, treatment, opioids, pain, bone metastases, prostate cancer

\section{Introduction}

The number of patients diagnosed with malignant tumours continues to rise along with new anticancer treatment possibilities, which together with effective symptomatic management prolong overall survival [1]. Among numerous problems of contemporary oncology, which appear with prolonged survival, one of the most important is the treatment of patients with bone metastases, especially those with spine secondaries. The presence of bone metastases is usually an evidence of advanced stage of cancer, significantly decrease patients' quality of life (QoL) and render a possibility of the development of potential life-threatening skeletal-related events (SRE), such as pathological bone fractures, including spine, spinal cord compression and hypercalcemia [2].

Bone metastases are present in $30-50 \%$ patients diagnosed with malignant tumors $[3,4]$, most frequently in the course of multiple myeloma (80-100\%), prostate $(70-75 \%)$, breast $(65-75 \%)$, thyroid $(50 \%)$, lung $(30-40 \%)$, malignant melanoma $(15-40 \%)$ and

\section{Adres do korespondencji:}

Marek Widenka

Hospicjum Domowe Niepubliczny Zakład Medycyny Paliatywnej w Kaliszu

e-mail: marekwidenka@op.pl 
renal cancer (20-25\%) [5-7]. Metastases are present 20-times more frequently compared to primary spine tumours [8], and the most frequent location is thoracic spine $(70 \%)$, and less frequently lumbar and cervical spine $[9,10]$. Regarding radiology picture, metastases may be divided into osteolytic and osteoblastic (osteosclerotic). However, due to the reciprocal influence of osteoclasts and osteoblasts bone metastases have no uniform type (i.e. exclusively osteolytic or osteoblastic). It rather may be characterized as bone metastases with predominant osteolytic (multiple myeloma, renal cancer, malignant melanoma) or predominant osteoblastic (prostate and breast cancer) [11].

Spine metastases significantly affect patients' QoL, mainly due to severe pain limiting patients' activity and performance status (PS), hypercalcemia symptoms, and also pathological fractures of vertebral bodies and paralysis induced by spinal cord compression $[12,13]$. In the diagnostic process, it is important to find out whether neurology complications are present, such as movement disturbances, dysesthesia and sphincter functions. In case of sudden and recent appearance of these symptoms, it is necessary to conduct diagnostic tests and appropriate therapeutic intervention. In each case, however, in order to diminish the consequences of spine metastases, maximizing patients' PS and QoL, and achieving possible improvement, it is necessary to undertake appropriate diagnostic investigations and treatment. Due to the complexity of problems, most frequently interdisciplinary approach is required [14].

\section{Case presentation}

67-year-old patient, a farmer, fit, professionally active, till 2014 did not need medical care. For 4 years irregularly consulted in urology outpatient clinic due to benign prostate hyperplasia. For 3 years complained about pain localized in a lumbar spine, intensifying during movements, and relieving at rest when lying. In this time patient received PRN doses of over the counter analgesics (paracetamol, ibuprofen, metamizol). In November 2017 due to the intensifying pain patient visited a family physician who diagnosed back pain, probably evoked by spondylarthrosis, and prescribed ketoprofen $100 \mathrm{mg}$ twice a day as intramuscular injections.

Due to the lack of analgesic effect and a change of the pain characteristics (radiation to thighs), after 3 weeks the patient was referred to Neurology Department. An MRI (magnetic resonance imaging) scan was conducted with multiple spondylarthrosis in a majority of vertebral bodies with accompanying discopathy on levels Th1/Th2, Th2/Th3, Th8/Th9, Th12/L1, L1/L2,
L2/L3, L3/L4, L5/S1 (without features of disco-radicular conflict) and L4/L5 with narrowing of the right intervertebral foramen and pressure on nerve roots. In all thoracic and lumbar vertebra and in sacral bone multiple foci of different size have been shown, which underwent heterogenous reinforcement after contrast administration - a picture of metastases. The height of the vertebral bodies was preserved.

Additionally, enlarged lymph nodes were demonstrated in the retroperitoneal space. In an X-ray of hips coxarthrosis with both sides sub-cartilage sclerotization and narrowing of a joint aperture at the right side. The chest X-ray was normal. Concurrently PSA (Prostate Specific Antigen) was assayed with significantly risen values (total PSA $>100.0 \mathrm{ng} / \mathrm{mL}$; free PSA > $50.0 \mathrm{ng} / \mathrm{mL}$ ). Prostate cancer with spine metastases was diagnosed. The patient was consulted by a neurosurgeon who disqualified the patient from a neurosurgical intervention.

The pain was treated with transdermal buprenorphine in the dose of $35 \mu \mathrm{g} / \mathrm{h}$, every 3 days and PRN 1-3 tablets per day of paracetamol with tramadol (325 mg $+37.5 \mathrm{mg}$, respectively). Additionally, dexamethasone $4 \mathrm{mg}$ twice daily IV was administered. Patient with a slight improvement in analgesia according to NRS (Numerical Rating Scale) 6-7 was discharged home with a recommendation of continuing analgesic regimen and conducting prostate biopsy in Urology Department and consultation in Oncology Outpatient Clinic.

Due to severe pain, intensifying confusion, and intense constipation patient was again consulted at home by family physician who stopped buprenorphine, and reinstituted ketoprofen $100 \mathrm{mg}$ and dexamethasone $4 \mathrm{mg}$ (both drugs administered orally twice daily), increased the dose of tramadol with paracetamol to 3 times daily $75 \mathrm{mg}+650 \mathrm{mg}$, respectively, and recommended glycerin suppositories PRN rectally and omeprazole $20 \mathrm{mg}$ once daily orally. Due to lack of improvement patient himself increased a dose of ketoprofen till $100 \mathrm{mg} \mathrm{3-4} \mathrm{times} \mathrm{a} \mathrm{day,} \mathrm{and}$ additionally took ibuprofen $200 \mathrm{mg}$ up to 3 times a day, metamizol $500 \mathrm{mg}$ twice a day and paracetamol $500 \mathrm{mg}$ 2-3 times a day orally. In Urology outpatient clinic prostate biopsy was conducted, histopathology: adenocarcinoma (Gleason $4+4$ ).

At the time of starting palliative care at home (Home Hospice) the patient in general was in a quite poor condition. Due to severe pain patient's activity was significantly limited: PS according to Karnofsky 40 and ECOG 3-4 [15]. Pain according to NRS (pain right now and average pain within last 2 weeks) 9-10. The pain was localized in lumbar region depicted as burning, radiating to both lower extremities with 
characteristics similar to electric shock-like sensations along the spine, which intensified during each activity - the patient was unable to stand up due to the pain. Physical examination showed limited movements of lower extremities induced by pain without radicular symptoms, weakness of proximal muscles and hyperesthesia of the skin of anterior surface of thighs, predominantly at the right side. PainDetect questionnaire result was 30/38, which confirmed a neuropathic pain component [16]. HADS-M (Hospital Anxiety and Depression Scale - Modified Version) result: depression 6/21, anxiety 15/21 - anxiety disorders [17].

Pain was managed with oxycodone/naloxone, starting from a dose of $10 \mathrm{mg}+5 \mathrm{mg}$, every $12 \mathrm{~h}$, subsequently with good treatment tolerance the dose was increased, every few days in the following order: $20 \mathrm{mg}+10 \mathrm{mg}$, every $12 \mathrm{~h} \rightarrow 30 \mathrm{mg}+15 \mathrm{mg}$, every $12 \mathrm{~h} \rightarrow 40 \mathrm{mg}+20 \mathrm{mg}$, every $12 \mathrm{~h}$. Ketoprofen administered orally at a dose of $100 \mathrm{mg}$ was continued. Concurrently, pregabalin as a co-analgesic was introduced in the form of capsules, starting at $75 \mathrm{mg}$ before sleep for 7 days, increasing the dose, every 7 days by $75 \mathrm{mg}$ ( $75 \mathrm{mg} /$ at night $\rightarrow 75 \mathrm{mg}$ twice daily $\rightarrow 75 \mathrm{mg}$ in the morning; $150 \mathrm{mg}$ at night $\rightarrow 150 \mathrm{mg}$ twice daily). Morphine sulfate immediate - release (IR) orally was used as a rescue analgesic, starting with a dose of $10 \mathrm{mg}$, increased to $20 \mathrm{mg}$, most often 60 minutes before planned hygienic procedures and rehabilitation. Dexamethasone was continued with tapering the dose to $2 \mathrm{mg}$ twice daily, omeprazole was substituted with esomeprazole at a dose of $40 \mathrm{mg}$ once daily (both drugs administered orally). Constipation was additionally treated with lactulose $20 \mathrm{ml}$ three times daily. A significant improvement in analgesia and PS was achieved and after 2 weeks the pain intensity right now and pain on average according to NRS equaled 3-4, and the patient was able to walk without assistance at his house, using PRN 1-2 tablets of $20 \mathrm{mg}$ of IR morphine sulphate per day, with improvement in anxiety. The patient had spontaneous bowel movements every 2 days.

Concurrently, zoledronic acid was introduced at a dose of $4 \mathrm{mg}$ every 21 days intravenously with vitamin D (2000 U per day) and calcium (400 mg calcium carbonate daily) supplementation, with surveillance of creatinine and ionized calcium concentrations in the blood serum. The first administration of the drug-induced para-flu symptoms - treatment comprised oral administration of paracetamol $500 \mathrm{mg} 3$ times daily for 2 days with good effect. After achieving satisfactory analgesia, dexamethasone was tapered to $2 \mathrm{mg}$ in the morning. The patient was referred for a consultation to Radiotherapy Unit for palliative radiotherapy of the lumbar spine.

\section{Discussion}

The presented patient was a farmer, working on his own farm, and interpreted the occurrence of his pain as a consequence of straining associated with physical effort, as the pain intensified during movement and relieved at rest. Until the pain was not too severe and limited to a spine area, the patient took over the counter analgesics and when lacking their efficacy at a next stage - drugs prescribed by a family physician. Only the appearance of severe pain disabling movements with radiation to lower extremities and accompanying weakness of muscle strength of lower extremities was a reason for hospital admission and conducting MRI scan. A weakness of muscle strength is the second most frequent symptom present in $35-75 \%$ of patients diagnosed with spine metastases at the moment of diagnosis [18]. Usually, patients complain about a feeling of heaviness in extremities, and in physical examination motor deficits are found which may be accompanied with dysesthesia, although a function of sphincters may still be preserved in earlier stages of spinal cord compression [19].

Pain may have different characteristics, but is one of the most frequent symptoms of spine metastases and is present in approximately $90 \%$ of patients [20]. Pain usually intensifies during palpation and percussion, and it may also resemble radicular pain induced by pressure on spinal nerve roots, or it may display pain exacerbated by movement and alleviated by rest [21,22]. Such diversity of pain characteristics is often the reason that patients are for a long time treated by family physicians, orthopedists, or neurologists with an assumption that a cause of a back pain is spondylarthrosis or discopathy, especially if in the medical history cancer was not diagnosed and patient is an active person who matches symptoms with excessive physical straining.

Diagnosis of bone metastases is possible with using several methods of imaging. X-ray is often a preliminary screening test because of common availability and low cost. A negative result, however, does not exclude the presence of bone metastases, which are clearly visible just after the destruction of nearly half of vertebral body [23]. Computed tomography (CT) is useful in the assessment of bone elements of the spine, including osteolytic or osteosclerotic changes, also a compressive fracture of the vertebral body. Main disadvantages of CT refer to the inability of differentiation of soft tissues and the necessity of contrast administration in the technic of myelography to show subarachnoid space; it is the reason why it is possible to show only $50 \%$ of changes in epidural space and in soft tissues [24]. A precise method of 
spine metastases diagnosis is MRI, which allows on multidimensional imaging in high fidelity of all spine elements, including bone structures and also for the differentiation of soft tissues, which enables to show the spinal cord, radicular nerves, intervertebral discs and paravertebral muscles. Bone scintigraphy and other isotope investigations such as positron emission tomography (PET) or single-photon emission computed tomography (SPECT) in imaging of bone metastases [25] should be also mentioned, although these are less available in Poland. After diagnosing of multiple spine metastases in case of presence of neurology symptoms urgent neurosurgeon consultation is recommended [26]. The depicted patient was disqualified from a neurosurgical intervention.

During the patient's stay in a hospital, pain was treated with buprenorphine and a composite product containing tramadol and paracetamol without any effect. Such treatment with concurrent use of analgesics from all steps of the WHO analgesic ladder (paracetamol, NSAIDs, tramadol and buprenorphine), usually is not practised [27]. In the depicted patient, these drugs induced adverse effects (AE): confusion and constipation. Despite the fact that buprenorphine belongs to the strong opioids preferred in older patients as well as in the treatment of neuropathic pain [28], due to lack of satisfactory analgesia and appearance of $A E$ the treatment was terminated. Another strong opioid which possesses evidenced efficacy in the treatment of chronic pain in cancer patients with neuropathic pain component is oxycodone [29]. However, due to the history of chronic constipation, oxycodone was used with naloxone [30], which allowed to relieve both pain and constipation. Treatment with ketoprofen was continued, and due to neuropathic pain component, pregabalin was added as a co-analgesic recommended in the management of this type of pain by the Polish Association for the Study of Pain and the Polish Association of Neurology [31, 32]. Due to the age of the patient the dose of pregabalin was carefully titrated with increments in doses every 7 days, which allowed avoiding $\mathrm{AE}$.

Further improvement in analgesia with a decrease of intensity of concurrent generalized anxiety, which may be matched with an additional anxiolytic effect of pregabalin, was observed [33]. In connection with an improvement and lack of symptoms of depression in HADS-M, antidepressants (venlafaxine, duloxetine) were not used, which are also recommended in the treatment of patients diagnosed with neuropathic pain $[31,34]$. Dexamethasone which was instituted at Neurology Department was continued with a gradual decrease of the dose. Such an approach was supported by a high probability of local activation of spinal nerve roots by metastases to vertebral bodies, which was based on symptoms and results of imaging investigations [35]. Because dexamethasone was co-administered with ketoprofen, prophylaxis was instituted with proton pump inhibitor (omeprazole, which was due to a lower risk of drug interactions subsequently substituted with esomeprazole) [36].

Bone metastases increase the risk of appearance of SRE [37]. SRE in the course of prostate cancer appear with the following frequency: radiotherapy $33 \%$, pathological fractures $25 \%$, hypercalcemia $25 \%$, spinal cord compression $8 \%$ and the necessity of surgical intervention $4 \%$ (combined frequency of SRE equals 49\%) [38]. Bisphosphonates display anticancer properties through blocking signal transmission between cancer cells and bone cells [39]. Bisphosphonates also prolong TTSRE (time to skeletal-related event) and prevent the appearance of SRE [40]. In the depicted patient a treatment with zoledronic acid was instituted intravenously and supplementation with calcium and vitamin D given by oral route. Additionally, due to a rehabilitation of the patient, high trunk orthosis was used to decrease the risk of SRE.

In a study that was a base for registration of zoledronic acid for the treatment of patients diagnosed with prostate cancer and bone metastases, apart from anticancer treatment, zoledronate was administered intravenously at a dose of $4 \mathrm{mg}$ or placebo every 21 days [40]. The primary outcome of the study was the frequency ratio of SRE in both patient groups during 15 months of the treatment. Significantly less SRE were found in the group of patients treated with zoledronate compared to those receiving placebo $(33 \%$ vs. $44 \%)$. Similarly, patients treated with zoledronate had significantly longer time (median) to the first SRE (488 days vs. 321 days). Apart from the aforementioned benefits the use of zoledronate was associated with less pain intensity as well as counteracted the development of osteoporosis, already present or induced by corticosteroids and hormone manipulations [41].

Among $A E$ of bisphosphonates administered through intravenous route should be listed electrolyte imbalance (most frequently hypocalcemia), renal function disturbances, jaws necrosis, and transient flu-like symptoms, which appear most often after the first administration of the drug. During the treatment with bisphosphonates should be conducted appropriate fluid supply, supplementation with vitamin $D$ and calcium, and assays of electrolytes, especially ionized calcium and eGFR before each bisphosphonate administration [42-44]. Before starting treatment with bisphosphonates a dentist consultation is required, and any necessary stomatology treatment should be 
instituted. During bisphosphonates treatment teeth extraction, implants institution, and other stomatology and facial-jaw surgical interventions should be avoided. Regular dental control every 3-4 months is recommended during bisphosphonate therapy [45].

Radiotherapy (RT) is deemed method of treatment of patients diagnosed with spine metastases. The aim of RT is to decrease pain intensity, improvement of patients' QoL and maintaining or improvement of bone system function. RT benefits concerning pain relief may be observed within a period of a few days to a few weeks, which should be considered in optimizing pharmacology treatment [46]. Apart from bone pain, other indications for RT in patients diagnosed with spine metastases comprise imminent or symptoms of spinal cord compression, threat or appearance of pathological fracture after surgical treatment. In the case of spine metastases transdermal vertebroplasty combined with complementary RT seems to be more beneficial compared to RT used alone in order to relieve pain, maintain the stability of the spine and improving patients' QoL [47]. Contraindications to RT are associated with a dose of former irradiation tolerated by critical organs, and in consequence lack of the possibility to repeat irradiation of a given location, which mainly refers to the spinal cord, guts, urinary bladder and very short (few days) predicted survival time [48].

In numerous randomized studies, similar analgesic efficacy of a single fraction (6-8 Gy) or multiple fractions (30 Gy in 10 fractions, $24 \mathrm{~Gy}$ in 6 fraction and $20 \mathrm{~Gy}$ in 5 fractions) was demonstrated $[49,50]$. Analgesic effect of RT regardless of fractionation method is observed in approximately $50-85 \%$ treated patients and in 30\% of treated patients pain completely disappears [51]. A complete or partial analgesic effect of RT in patients diagnosed with bone metastases usually appears in the period of 4 weeks since RT and the mean time of remission lasts for approximately 19 weeks [52]. The response rate is higher, and the remission period is longer in patients diagnosed with breast and prostate cancer compared to those diagnosed with lung and other primary tumour locations [53].

Another treatment method that is used independently or in combination with local RT and other types of treatment in patients diagnosed with multiple spine metastases in the course of prostate cancer are radioisotopes. This treatment method is used in patients with osteoblastic or mixed metastases, sometimes before the clinical symptoms appear, which decrease the number of new pain areas and risk of pathological fractures. The use of radioisotopes decreases pain intensity and number of SRE and improves patients' QoL [54].
The treatment used improved overall PS and QoL and regained the patient self-care, which allowed to refer the patient for consultations and further treatment to Radiotherapy Unit and Urology Outpatient Clinic.

\section{Conclusions}

Cancer patients with spine metastases often visit physicians with numerous and complex diagnostic and/or therapeutic problems that require integrated care. Diagnostic and therapeutic management requires cooperation between different specialists, including orthopedist, neurologist, neurosurgeon, radiotherapist, nuclear medicine and palliative medicine specialist, and also specialists for the treatment of cancer: urologist - prostate and renal cancer, pulmonologist - lung cancer, haematologist - multiple myeloma, oncologist - other tumours. Such physicians team should additionally cooperate with a nurse, physiotherapist, psychologist, social worker, medical career and a chaplain. The additional condition that is necessary to improve patients' QoL, independent from a prognosis, is a provision of appropriate coordination of care and integration of proposed treatment. Such an interdisciplinary approach gives a chance for better care for a patient in a difficult clinical situation as the presence of multiple spine metastases is.

\section{References}

1. Hayat MJ, Howlader N, Reichman ME, et al. Cancer statistics, trends, and multiple primary cancer analyses from the Surveillance, Epidemiology, and End Results (SEER) Program. Oncologist. 2007; 12(1): 20-37, doi: 10.1634/theoncologist.12-1-20, indexed in Pubmed: 17227898.

2. Zdrojowy R. Kwas zoledronowy - znaczenie w zapobieganiu i leczeniu powikłań związanych z przerzutami do kości. Przegl Urol. 2004; 23: 16-20.

3. Heidecke V, Rainov NG, Burkert W. Results and outcome of neurosurgical treatment for extradural metastases in the cervical spine. Acta Neurochir (Wien). 2003; 145(10): 873-80; discussion 880, doi: 10.1007/s00701-003-0107-1, indexed in Pubmed: 14577009.

4. Ortiz Gómez JA. The incidence of vertebral body metastases. Int Orthop. 1995; 19(5): 309-311, indexed in Pubmed: 8567140.

5. Camins MB, Jenkins AL, Singhal A, Perrin RG. Tumors of the vertebral axis: benign, primary malignant, and metastatic tumors. In: Winn RH, Youmans JR. ed. Youmans neurological surgery. 5th ed. Saunders Company, Philadelphia 2004: 4835-4868.

6. Jacobs WB, Perrin RG. Evaluation and treatment of spinal metastases: an overview. Neurosurg Focus. 2001; 11(6): e10, indexed in Pubmed: 16463993.

7. Coleman R. Skeletal complications of malignancy. Cancer. 1997; 80(S8): 1588-1594, doi: 10.1002/(sici)1097-0142 (19971015)80:8+<1588::aid-cncr9>3.0.co;2-g.

8. Perrin RG, Laxton AW. Metastatic spine disease: epidemiology, pathophysiology, and evaluation of patients. Neu- 
rosurg Clin N Am. 2004; 15(4): 365-373, doi: 10.1016/j. nec.2004.04.018, indexed in Pubmed: 15450871.

9. Steinmetz MP, Mekhail A, Benzel EC. Management of metastatic tumors of the spine: strategies and operative indications. Neurosurg Focus. 2001; 11(6): e2, indexed in Pubmed: 16463994.

10. Holman PJ, Suki D, McCutcheon I, et al. Surgical management of metastatic disease of the lumbar spine: experience with 139 patients. J Neurosurg Spine. 2005; 2(5): 550-563, doi: 10.3171/spi.2005.2.5.0550, indexed in Pubmed: 15945429.

11. Drosik K, Krzakowski M, Jarosz J, et al. Bisfosfoniany w zapobieganiu i kontroli zdarzeń kostnych u chorych z przerzutami nowotworów złośliwych do kości. Onkol Prakt Klin. 2006; 2: 152-164.

12. Ibrahim A, Crockard A, Antonietti $P$, et al. Does spinal surgery improve the quality of life for those with extradural (spinal) osseous metastases? An international multicenter prospective observational study of 223 patients. Invited submission from the Joint Section Meeting on Disorders of the Spine and Peripheral Nerves, March 2007. J Neurosurg Spine. 2008; 8(3): 271-278, doi: 10.3171/SPI/2008/8/3/271, indexed in Pubmed: 18312079.

13. Patchell $R$, Tibbs $P$, Regine $W$, et al. Direct decompressive surgical resection in the treatment of spinal cord compression caused by metastatic cancer: a randomised trial. The Lancet. 2005; 366(9486): 643-648, doi: 10.1016/s01406736(05)66954-1.

14. Harel R, Angelov L. Spine metastases: current treatments and future directions. Eur J Cancer. 2010; 46(15): 26962707, doi: 10.1016/j.ejca.2010.04.025, indexed in Pubmed: 20627705.

15. Jang RW, Caraiscos VB, Swami N, et al. Simple prognostic model for patients with advanced cancer based on performance status. J Oncol Pract. 2014; 10(5): e335-e341, doi: 10.1200/JOP.2014.001457, indexed in Pubmed: 25118208.

16. Bisaga W, Dorazil M, Dobrogowski J, et al. Porównanie przydatności wybranych skal oceny bólu neuropatycznego u pacjentów z przewlekłymi zespołami bólowymi: krótkie doniesienie. Med Paliat Prakt. 2011; 5: 22-26.

17. De Walden-Gałuszko K, Majkowicz M. Ocena jakości opieki paliatywnej w teorii i praktyce. Akademia Medyczna w Gdańsku, Gdańsk 2000: 34-36.

18. van der Linden YM, Dijkstra SP, Vonk EJA, et al. Dutch Bone Metastasis Study Group. Prediction of survival in patients with metastases in the spinal column: results based on a randomized trial of radiotherapy. Cancer. 2005; 103(2): 320-328, doi: 10.1002/cncr.20756, indexed in Pubmed: 15593360.

19. Cole J, Patchell R. Metastatic epidural spinal cord compression. The Lancet Neurology. 2008; 7(5): 459-466, doi: 10.1016/s1474-4422(08)70089-9.

20. Helweg-Larsen S, Sørensen PS. Symptoms and signs in metastatic spinal cord compression: a study of progression from first symptom until diagnosis in 153 patients. Eur J Cancer. 1994; 30A(3): 396-398, indexed in Pubmed: 8204366.

21. Yang Z, Yang D, Xie L, et al. Treatment of metastatic spinal tumors by percutaneous vertebroplasty versus percutaneous vertebroplasty combined with interstitial implantation of $125 \mathrm{I}$ seeds. Acta Radiol. 2009; 50(10): 1142-1148, doi: 10.3109/02841850903229133, indexed in Pubmed: 19922311.

22. Witham TF, Khavkin YA, Gallia GL, et al. Surgery insight: current management of epidural spinal cord compression from metastatic spine disease. Nat Clin Pract Neurol. 2006; 2(2): 87-94; quiz 116, doi: 10.1038/ncpneuro0116, indexed in Pubmed: 16932530.
23. Costelloe CM, Rohren EM, Madewell JE, et al. Imaging bone metastases in breast cancer: techniques and recommendations for diagnosis. Lancet Oncol. 2009; 10(6): 606-614, doi: 10.1016/S1470-2045(09)70088-9, indexed in Pubmed: 19482249.

24. Guillevin R, Vallee JN, Lafitte $F$, et al. Spine metastasis imaging: review of the literature. J Neuroradiol. 2007; 34(5): 311-321, doi: 10.1016/j.neurad.2007.05.003, indexed in Pubmed: 17628678.

25. Daldrup-Link HE, Franzius C, Link TM, et al. Whole-body MR imaging for detection of bone metastases in children and young adults: comparison with skeletal scintigraphy and FDG PET. AJR Am J Roentgenol. 2001; 177(1): 229236, doi: 10.2214/ajr.177.1.1770229, indexed in Pubmed: 11418435.

26. Fehlings MG, David KS, Vialle L, et al. Decision making in the surgical treatment of cervical spine metastases. Spine (Phila Pa 1976). 2009; 34(22 Suppl): S108-S117, doi: 10.1097/BRS.0b013e3181bae1d2, indexed in Pubmed: 19829270.

27. Kotlińska-Lemieszek A, Deskur-Śmielecka E, Kluziak M, et al. Leczenie bólów nowotworowych - w oparciu o aktualną wiedzę. Now Lek. 2011; 80: 22-31.

28. Widenka M, Leppert W. The role of transdermal buprenorphine in the treatment ofchronic pain in elderly patients. Ból. 2016; 17(3): 53-63, doi: 10.5604/01.3001.0009.5274.

29. King SJ, Reid C, Forbes $K$, et al. A systematic review of oxycodone in the management of cancer pain. Pain Pract. 2014; 14: 32-42.

30. Morlion BJ, Mueller-Lissner SA, Vellucci R, et al. Oral Prolonged-Release Oxycodone/Naloxone for Managing Pain and Opioid-Induced Constipation: A Review of the Evidence. Pain Pract. 2018; 18(5): 647-665, doi: 10.1111/papr.12646, indexed in Pubmed: 28944983.

31. Szczudlik A, Dobrogowski J, Wordliczek J, et al. Rozpoznanie i leczenie bólu neuropatycznego: przegląd piśmiennictwa i zalecenia Polskiego Towarzystwa Badania Bólu i Towarzystwa Neurologicznego - część pierwsza. Ból. 2014; 15: 8-18.

32. Raptis E, Vadalouca A, Stavropoulou E, et al. Pregabalin vs. opioids for the treatment of neuropathic cancer pain: a prospective, head-to-head, randomized, open-label study. Int J Clin Pract. 2010; 64: 1301-1309.

33. Bandelow B, Michaelis S, Wedekind D. Treatment of anxiety disorders. Ann Oncol. 2006; 17: 986-989.

34. Nishihara M, Arai YCP, Yamamoto $Y$, et al. Combinations of low-dose antidepressants and low-dose pregabalin as useful adjuvants to opioids for intractable, painful bone metastases. Palliat Med. 2011; 25: 454-470.

35. Tsuzuki S, Park SH, Eber MR, et al. Skeletal complications in cancer patients with bone metastases. Int J Urol. 2016; 23(10): 825-832, doi: 10.1111/iju.13170, indexed in Pubmed: 27488133.

36. Masclee GMC, Valkhoff VE, Coloma PM, et al. Risk of upper gastrointestinal bleeding from different drug combinations. Gastroenterology. 2014; 147(4): 784-792.e9; quiz e13, doi: 10.1053/j.gastro.2014.06.007, indexed in Pubmed: 24937265.

37. So A, Chin J, Fleshner N, et al. Management of skeletal-related events in patients with advanced prostate cancer and bone metastases: Incorporating new agents into clinical practice. Can Urol Assoc J. 2012; 6(6): 465-470, doi: 10.5489/cuaj.12149, indexed in Pubmed: 23282666.

38. Coleman RE. Bisphosphonates: clinical experience. Oncologist. 2004; 9 Suppl 4: 14-27, doi: 10.1634/theoncologist.9-90004-14, indexed in Pubmed: 15459426.

39. Fleisch H. Bisphosphonates: Background to the pharmacological development. In: Fleisch H. ed. Bisphosphonates 
in bone disease: from the laboratory to the patient. Wyd. 4. Academic Press Inc., London, New York 2000.

40. Saad F, Gleason DM, Murray R, et al. Zoledronic Acid Prostate Cancer Study Group. A randomized, placebo-controlled trial of zoledronic acid in patients with hormone-refractory metastatic prostate carcinoma. J Natl Cancer Inst. 2002; 94(19): 1458-1468, indexed in Pubmed: 12359855.

41. Tupikowski K, Zdrojowy R. Zapobieganie uszkodzeniom tkanki kostnej oraz ich leczenie u chorych na raka gruczołu krokowego - zagadnienia wybrane. Przegląd Urologiczny. 2007; 43: 73-78.

42. Drake MT, Clarke BL, Khosla S. Bisphosphonates: mechanism of action and role in clinical practice. Mayo Clin Proc. 2008; 83(9): 1032-1045, doi: 10.4065/83.9.1032, indexed in Pubmed: 18775204.

43. Chang JT, Green L, Beitz J. Renal failure with the use of zoledronic acid. N Engl J Med. 2003; 349(17): 1676-9; discussion 1676, doi: 10.1056/NEJM200310233491721, indexed in Pubmed: 14573746.

44. Durie BGM, Katz M, Crowley J. Osteonecrosis of the jaw and bisphosphonates. N Engl J Med. 2005; 353(1): 99-102; discussion 99, doi: 10.1056/NEJM200507073530120, indexed in Pubmed: 16000365.

45. Litwiniuk M, Staszkiewicz A. Martwica kości szczęk po długotrwałym stosowaniu bisfosfonianów. Onkol Prakt Klin. 2007; 3: 306-310.

46. Lutz $\mathrm{S}$. The role of radiation therapy in controlling painful bone metastases. Curr Pain Headache Rep. 2012; 16(4): 300-306, doi: 10.1007/s11916-012-0271-1, indexed in Pubmed: 22576786.

47. Cao XY, Liu YS, Lei MX, et al. [Comparison of curative effect and prognosis analysis of patients with spinal metastases treated by percutaneous vertebroplasty combined with postoperative radiotherapy and radiotherapy alone]. Zhonghua Yi Xue Za Zhi. 2016; 96(47): 3805-3810, doi: 10.3760/cma.j.issn.0376-2491.2016.47.008, indexed in Pubmed: 28057095.

48. Rolski W, Kiprian D, Kawecki A. Radioterapia paliatywna w leczeniu przerzutów do kości. Med Paliat. 2011; 2: 95-100.

49. Chow E, Harris K, Fan G, et al. Palliative radiotherapy trials for bone metastases: a systematic review. J Clin Oncol. 2007; 25(11): 1423-1436, doi: 10.1200/JCO.2006.09.5281, indexed in Pubmed: 17416863.

50. Hartsell WF, Scott CB, Bruner DW, et al. Randomized trial of short- versus long-course radiotherapy for palliation of painful bone metastases. J Natl Cancer Inst. 2005; 97(11): 798-804, doi: 10.1093/jnci/dji139, indexed in Pubmed: 15928300.

51. Lutz S, Berk L, Chang E, et al. American Society for Radiation Oncology (ASTRO). Palliative radiotherapy for bone metastases: an ASTRO evidence-based guideline. Int J Radiat Oncol Biol Phys. 2011; 79(4): 965-976, doi: 10.1016/j. ijrobp.2010.11.026, indexed in Pubmed: 21277118.

52. De Felice F, Piccioli A, Musio D, et al. The role of radiation therapy in bone metastases management. Oncotarget. 2017; 8(15): 25691-25699, doi: 10.18632/oncotarget.14823, indexed in Pubmed: 28148890.

53. van der Linden YM, Lok JJ, Steenland E, et al. Dutch Bone Metastasis Study Group. Single fraction radiotherapy is efficacious: a further analysis of the Dutch Bone Metastasis Study controlling for the influence of retreatment. Int J Radiat Oncol Biol Phys. 2004; 59(2): 528-537, doi: 10.1016/j. ijrobp. 2003.10.006, indexed in Pubmed: 15145173.

54. Ryan CJ, Saylor PJ, Everly JJ, et al. Bone-targeting radiopharmaceuticals for the treatment of bone-metastatic castration-resistant prostate cancer: exploring the implications of new data. Oncologist. 2014; 19(10): 1012-1018, doi: 10.1634/theoncologist.2013-0472, indexed in Pubmed: 25232039. 